\title{
Integrating marine ecosystem conservation and ecosystems services economic valuation: Implications for coastal zones governance
}

\author{
Ana Margarida Ferreira ${ }^{\mathrm{a}, \mathrm{b}, *}$, João Carlos Marques ${ }^{\mathrm{b}}$, Sónia Seixas ${ }^{\mathrm{b}, \mathrm{c}}$ \\ a Environment Municipal Company of Cascais (Cascais Ambiente), Complexo Multiserviços, Estrada de Manique no. 1830, 2645-550, Alcabideche, Portugal \\ ${ }^{\mathrm{b}}$ Marine and Environmental Sciences Centre (MARE), Department of Life Sciences, University of Coimbra, Portugal \\ c Universidade Aberta, Rua Escola Politécnica, no. 147, 1269-001, Portugal
}

\section{A R T I C L E I N F O}

\section{Article history:}

Received 14 October 2016

Received in revised form 26 January 2017

Accepted 29 January 2017

\section{Keywords:}

Marine protected areas

Coastal zone conservation

Contingent valuation

Willing to pay

Voluntary work

\begin{abstract}
A B S T R A C T
This paper presents a preliminary attempt to estimate the awareness and value that society gives to the maintenance and protection of marine protected areas, linking the ecological and economic value scale assigned to the study. To accomplish this, we took as illustrative example the Biophysical Interest Zone of Avencas (ZIBA), in Portugal. The ZIBA spans over one ha and its coastal ecosystems present a very rich biodiversity, providing several socio-economic opportunities to society. To estimate the value that society attributes to this area we conducted a contingent valuation exercise, considering two different aspects: 1) the direct economic value that people state to conserve the ecosystem and 2) the willingness to contribute through the allocation of hours of voluntary work to its conservation. The values obtained indicate the dependence and importance of this ecosystem to local population (willing to pay to conserve it of $60 €$ per household per year and willing to give $3 \mathrm{~h}$ of voluntary work per year). The proximity of the local population to the protected area increases the willing to pay for its conservation; this could reveal a good local indicator of ecosystem valuation. This valuation exercise highlights the importance of coastal ecosystem services to society and draws attention to the benefits that local populations derive from those systems. These results have also implications in future governance actions regarding protected areas, as well as to justify for sustainable investments in coastal management efforts, to sustain the flow of coastal ecosystem services for current and future generations.
\end{abstract}

C 2017 Published by Elsevier Ltd.

\section{Introduction}

Coastal zones are open land/sea interfaces, exposed to strong environmental gradients that establish high connectivity with other coastal ecosystems (Thompson et al., 2002). This is an area exposed to several different environmental and human pressures. The anthropogenic pressure is continually rising due to the growing human population concentration in the shores, causing pollution problems and the overexploitation of natural resources for food purposes. It is equally an area with great richness in biological diversity and valuable habitats, like the coastal reefs. Particularly in rocky shores, the existence of several reef species that migrate between rocky reefs (Gladstone 2007) is an important characteristic to the maintenance of the coastal ecosystem.

\footnotetext{
* Corresponding author at: Environment Municipal Company of Cascais (Cascais Ambiente), Complexo Multiserviços, Estrada de Manique no. 1830, 2645-550, Alcabideche, Portugal.

E-mail address: ana.ferreira@cascaisambiente.pt (A.M. Ferreira).
}

Marine Protected Areas (MPA) are good management instruments to maintain the coastal zone biodiversity. In Portugal, the first protected area encompassing marine territory was classified in 1981 , and in the present days there is a record of 16 places with some protection status that include marine territory. Traditionally this classification occurred without a strong public participation and with many conflict of interests, transforming the management of these areas into a challenge (Ferreira et al., 2015).

From the human society perspective, the coastal zones and MPA provide an innumerous range of services. They are leisure areas and an important food source, where several industrial and touristic activities take place. This intensive use of coastal areas causes competition for the occupation of these regions and requires for techniques and methods that quantify the social, ecological and economic benefits that humans take from these systems. An ecosystem total economic value (TEV) consists of use and non-use values. By use values we can have direct (like food) and indirect (like recreation) values. The non-use values are usually associated with the conservation/preservation of the ecosystem for option future uses or bequest values (Kriström 1990; Bateman et al., 2002). There are 
several methods to value ecosystem services to society, however this study will focus only in one methodology (contingent valuation), due to the importance for society of the non-use values in this case study: a coastal protected area easily accessible to the population where no entrance fee is collected. Contingent valuation is a survey-based technique for stating the preferences of non-use values or indirect values to society, over other items of private consumption. It is the most commonly used approach to placing a monetary value on non-use environmental resources (Boyle and Bishop 1988; Mitchell and Carson, 1989; Bateman et al., 2002).

The contribution to nature conservation in form of volunteer work could be a family activity increasingly valued by the population as a practice of teaching values and bonding with the future generations. The willing to spend time in activities like beach clean ups, invasive species eradication or native species plantation, is considered a form of leisure wile contributing to nature conservation, especially in urban nucleus were nature activities are not normally available. García-Llorente et al. (2015) propose willingness to give up time in contingent valuation studies, as a useful non-monetary technique, particularly in areas with economic limitations.

With the current scenario of economic crisis, governments have cut backs in their annual budgets. Investment is mostly in social services and local economic empowerment, with the main objective of decreasing the unemployment rate and poverty. Therefore, although nature and coastal zone ecosystem services remain indispensable to the population, during a financial and economic crisis there is a risk of that being relegated to the bottom of the political agenda priorities. Communication of the importance of these ecosystem services to the policy makers, in a simple way, could increase the importance allocated to its conservation.

When conducting a multiple indicator study to communicate similar ecological outcomes, Zhao et al. (2013) demonstrated that in valuation studies, when the ecological indicator of ecosystem services are equivalent, the correspondent valuation measure used, is robust to the use of alternative ecological indicators within the survey scenarios. This approach can be beneficiary when communicating with managers and policy makers once contingent valuation studies are a major tool to justify investments in nature conservation, namely in the coastal zones, because they quantify in money (in this case euros), just how much the services provided by this ecosystem are valued by the population. With this type of information, coastal zone managers can develop a cost benefit-analysis, prioritizing investments in its territory, like a specific budget to erosion problems in the shore, investments in environmental education, and investments in pollution emergency plans, or nature restoration initiatives. They can also compare the benefits of different projects or programs, maximizing the public wellbeing with the investments made.

In Chile, Gelcich et al. (2013) reported a 97\% rate of respondents willing to pay (WTP) for the financing of a marine protected area with the charge of an entrance fee, covering 10-13\% of the MPA running costs. The same tendency was reported in Croatia, over $80 \%$ of the interviewees were WTP for their holiday in support of marine conservation (Batela et al., 2014). From the tourist perspective the availability to pay an extra amount while visiting a particular area for nature conservation is well recorded: sun-sea-sand tourists report a median WTP of US\$3.77, while nature based tourists state a higher WTP value of US\$ 4.38 (Gelcich et al., 2013) for nature conservation. In Kentucky it was recorded a WTP value between US\$ 6 and US\$ 13 for a "Wetland Preservation Fund" (Whitehead 1990), and in Spain, the results showed that the mean WTP for an improvement in water quality was about $€ 33$ per household per year (Ramajo-Hernandez and Saz-Salazar 2012).

This type of studies can never alone provide the definitive answer to any major policy question; they help to provide man- agers a more complete package of information, allowing them to make choices concerning the provision of the particular environmental amenity in a forward-looking manner (Carson 1998).

The objective of this work is to determine the valuation of a protected area in a distance decay perspective and the population's (users and non-users of the area) willing to pay or to give time for marine ecosystem conservation of the area and its cultural services, from a management perspective. The use of a non-monetary technic as the willing to give up time in nature's conservation is not commonly used in contingent valuation studies, and intends to be an innovative perspective for the management of coastal protected areas.

More specifically, this study was aimed to:

1. Determine if the socio-economic characteristics, distance to the area and usage of the population, influences the willing to pay or to give time for coastal zone conservation;

2. Determine the value that people are willing to pay for costal zones conservation in $€$ and voluntary work as a proxy to traditional willing to pay; and

3. Determine the reason for that willing to pay for coastal zones conservation.

\section{Methods}

\subsection{Study-site description}

The Biophysical Interest Zone of Avencas (ZIBA), located in Cascais municipality (Portugal) (Fig. 1), is characterized by extended calcareous rocky platforms with a small sandy beach in the middle (Avencas beach) sheltered from the dominant north winds. This beach is a type III beach (semi-natural beach) with a carrying capacity of 156 people in total (considering that each person occupies $12 \mathrm{~m}^{2}$ of sand while at the beach) (POOC, 1998).

ZIBA was classified as a Biophysical Interest Zone in 1998 by the National Coastal Management Plan (Cidadela - São Julião da Barra) (POOC, 1998) because of its intertidal biodiversity richness and geological particularities. Activities as fishing or motor boat sailing are prohibited as a function of the statute of protected area.

Several schools and universities use this area to perform their field trips all year round (Ferreira et al., 2015). Tide pooling and swimming are important activities in the summer. This rocky shore has also an historical and therapeutic interest due to its renowned health benefits in treating bone disease with natural limestone.

Avencas beach users are constantly exceeding the carrying capacity of the place. Trampling of the rocky shore, along with illegal fishing and human disturbance at the reproduction time of local marine species (spring and summer) are the main pressures identified for this protected area (Ferreira et al., 2015).

\subsection{Questionnaire implementation}

We conducted a pre-test before the surveys, in May 2014, to ensure that respondents understood correctly the survey questions and scenarios and to test if the classes included in the payment card were adequate. The full survey was implemented during the 2014 summer season (between 1st of June and 30th of September), comprehending 300 face-to-face surveys (100 surveys at each municipality) at three different coastal municipalities with the same touristic characteristic in the summer, being visited during this season for their beaches. Cascais is the municipality of the protected area (distance $=0 \mathrm{~km}$ ), Almada is the municipality located to a distance of $40 \mathrm{~km}$ and Aveiro is the most distant municipality, located to a distance of $250 \mathrm{~km}$. (Fig. 1). We have chosen this period in order to ensure that most of the population targeted by the ques- 


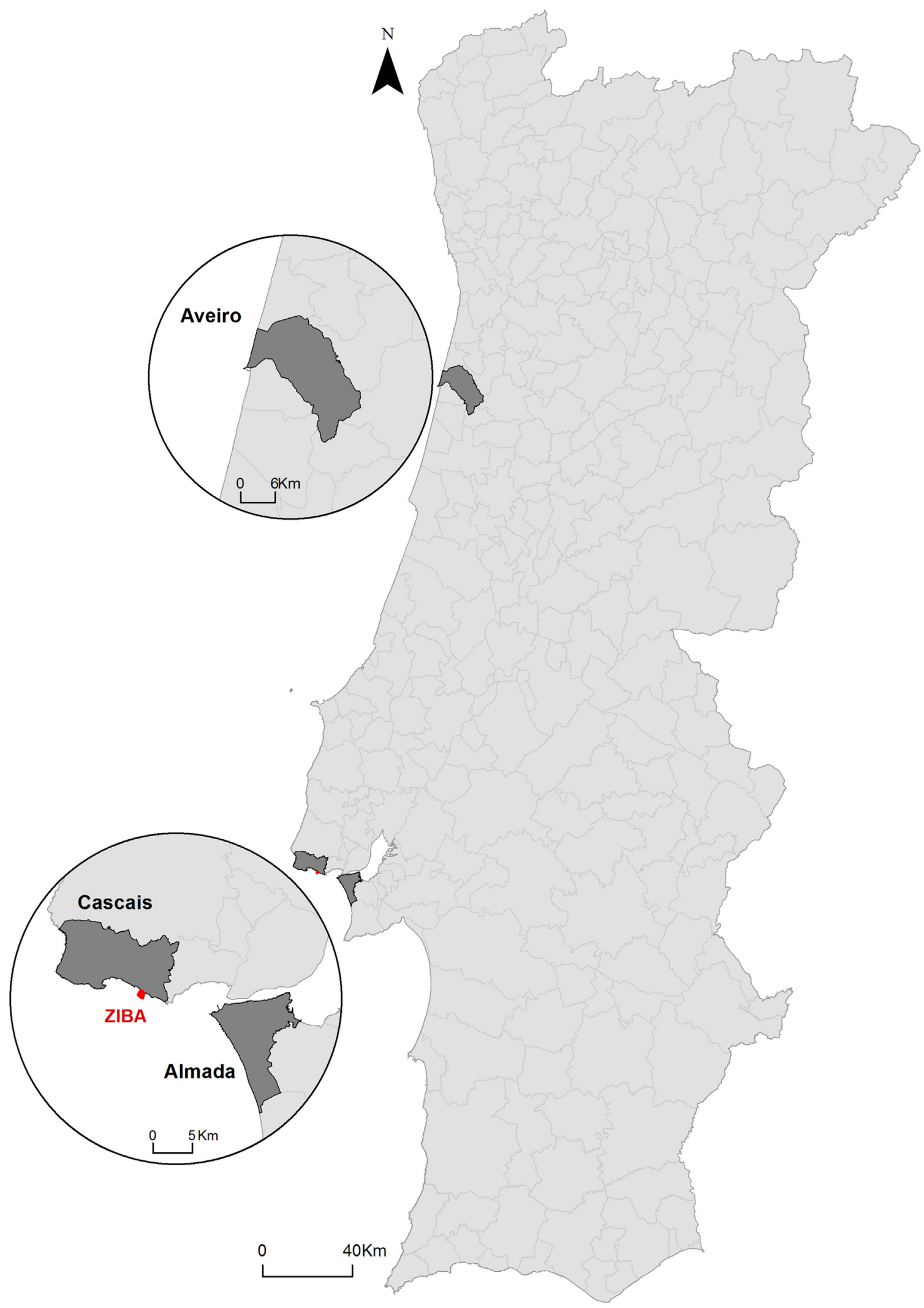

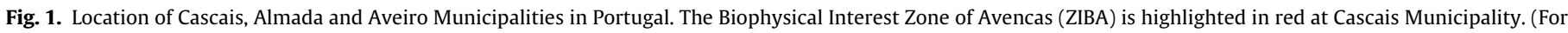
interpretation of the references to colour in this figure legend, the reader is referred to the web version of this article.)

tionnaires consisted of both users (local population) and non-users (tourists) of the system. The surveys were conducted by the authors and by volunteers trained for this purpose and were performed independently. We randomly selected the respondents from public locations in the municipalities approaching every individual in 
the space and always ensuring that respondents were older than 18 years-old.

\subsubsection{Questionnaire structure and scenarios}

The questionnaires consisted of three sections of questions to assess the population WTP for nature conservation in a local marine protected area, the ZIBA in Cascais. The first section aimed to characterize the population usage of coastal zones, aiming to get the respondent thinking about the study area and the main benefits they obtained with it. The second section analyzed the population knowledge about ZIBA and its ecosystem services. In this section, we introduced the valuation question aiming at determining the population willing to pay for the maintenance of its non-use benefits. Finally, the last section inferred about the population socioeconomic characteristics.

We presented two scenarios to respondents to analyse their preferences towards the ZIBAs marine ecosystem conservation and maintenance. The main attributes considered in the scenarios development were increase in: a) the limits of the protected area; b) biodiversity; environmental education activities; c) leisure activities; d) environmental patrolling; and e) information spots and visitation pathways. We presented and explained these scenarios to the surveyed population, always comparing it to the status-quo situation, to estimate their willing to pay.

We considered two types of contributions: a monetary WTP and/or a voluntary time contribution, subsequently converting the last into monetary values by calculating the average income of an individual in Portugal in 2014 ( $5 € / h$ ) (INE, 2011).

In the surveys, a payment card (with values ranging between 0 and $>45 €$ ) was adopted as the elicitation format and the payment vehicle considered was an increase in the monthly water bill as a taxation. The survey contained two preference elicitation questions: 1) a 'yes or no' response to the tax increase proposal; and 2) an open-ended question that asked the maximum tax that the respondent would be willing to pay. We considered the following text to estimate the monetary value given by respondents: 'How much would you be willing to add to your monthly water bill, as taxation, so that ZIBA could be improved? This monthly contribution would guarantee the installation of information spots, environmental education to the scholar public, environmental outreach to the general public?' We addressed a question to infer about their ability to give time (as voluntary work) and help to conserve the system (with values between 0 and $36 \mathrm{~h}$ per year, assuming that each volunteering activity takes about $3 \mathrm{~h}$ in average). After the questions, we conducted a debriefing section to gain insight into the reasons for the response to the preference questions. Respondents were asked to state the reasons underlying their willing to pay for coastal zones conservation, though the use of a five-point Likert scale (Likert 1932), ranging from "fully agree" to "totally disagree" (Figs. 2-5 ).

\subsubsection{Sensitivity to scale}

For this analysis, and aiming to infer the Avencas socioecological importance, a distance-decay exercise was considered. Moving from the study site itself, three locations were considered: Cascais, Almada, and Aveiro. Cascais Municipality is located in the Lisbon Metropolitan Area (Portugal). In the 2011 census, it had a total population of 206,479 inhabitants (INE, 2011). Almada Municipality is also located in the Lisbon Metropolitan Area being a $40 \mathrm{~km}$ drive from Cascais, with a population of 174,030 inhabitants (INE, 2011). Aveiro Municipality is located farther north (about $250 \mathrm{~km}$ of distance from Cascais) and presented a total of 78,450 inhabitants in 2011 (INE, 2011). These three locations were selected because they present some similarities on how populations use coastal systems, typically mainly for touristic usages. Therefore, it was assumed that the local population had the same characteristic affinity towards the sea, being the only differential factor its distance to the protected area.

\subsection{Statistical analysis}

The survey respondents were organized into two different groups in order to determine if the socio-economic characteristics of the population influences the willing to pay for coastal zone conservation. We expected that populations' willingness to contribute to nature conservation increased as the household budget also increased. The first group (hereafter Group 1) consisted of all individuals' sampled - individuals older than 18 years-old. The second group (hereafter Group 2) consisted of all the individuals sampled older than 18 years-old, except the ones that were unemployed, students or did not have a full employment occupation individuals older than 18 years-old with an income.

Through the surveys implementation it was possible calculate the percentage of people that were willing to pay for costal zones conservation in the form of a tax added to their water bill (measured in euros), and the percentage of people that were willing to allocate time to conduct voluntary work in coastal conservation (measured in hours). The maximum annual value was calculated for each of the classes given in the survey, using the mid-point estimates.

Additionally, Spearman correlation analyses were also performed to infer the main reasons influencing the respondents' WTP or to give time. The null hypothesis being tested is the inexistence of correlation between WTP or to give time and the different reasons presented for a positive or a negative answer. Protests were also identified through follow-up questions. Although there is not a specific methodology to identify protest answers, these can be distinguished from true zero answers through de-briefing questions, where respondents enumerate the main reasons for their refusal to contribute.

Spearman correlations were also performed to identify the main uses of the population regarding the coastal zone and its relation to WTP. The null hypothesis being tested is the inexistence of correlation between WTP and the different usages of the coastal zone considered in the questionnaire.

The Spearman correlation analyses were conducted, using the SPSS software (IBM SPSS Statistics V21).

\section{Results}

\subsection{Descriptive statistics of the surveyed sample}

Three hundred in person surveys were conducted. From these, four were deleted due to missing information and inconsistencies in the answers. From the 296 useable surveys, 100 were from Cascais, 97 from Almada and finally 99 from Aveiro.

Descriptive statistics of the respondents' characteristics of Group 1 are reported in Table 1 . The representativeness of the respondents surveyed was determined by comparing the different socio-economic parameters from the respondents sample with the national average values (2011 demographic census; INE, 2011). Small variances were found between mean ages (national $=41.16$, considered municipalities $=40.18$ ), mean household size (national $=2.60$ and considered municipalities $=2.86$ ) and gender (female percentages: national $=52.20 \%$, considered municipalities $=61.25 \%$ ) for the national and regional samples. Following the same pattern, the percentage of people with a university level of education in the sample was higher than the one recorded for the entire country: 48 and 15\%, respectively (Table 1). Consequently, the average monthly income per household is also higher for the surveyed population compared with the national average (most of the surveyed population falls within the 1001-2000€ income 
1. The Municipality is doing a good job in this area and I want to pay a little bit more to support the improvements in quality

2. I want to contribue to the aquatic environment protection and for the preservation of the aquatic animals and plants

3. Moraly I felt that this was the right answer

4. I am interested in the improvements, no matter the costs

5. The improvements will be valued by me and my family

6. It will be a good investment for generations to come
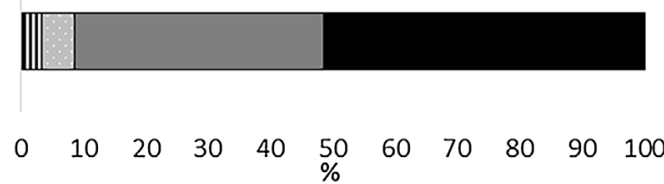

๑totally disagree m disagree
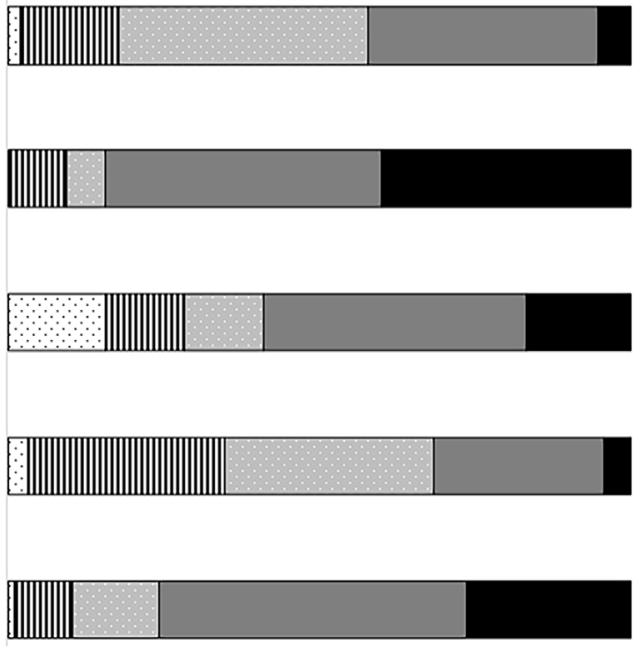

$\square$ agree in part $\square$ agree $\mathbf{\square}$ fully agree

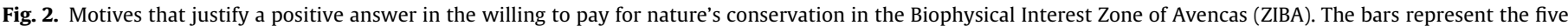
levels of the Likert scale in percentage values.

1.I rather use my money in something else

2. I think that the actual environmental quality is enough

3. Those who polute and destroy the environmental quality of the coastal zone are the ones who should pay for its conservation and improvement

4. The Municipality is the one that should support for the environmental quality improvements

5. The users of the Biophysical Interest Zone of Avencas are the ones that should pay for the environmental quality improvements.

6. I rather pay for nature conservation in another location

7. The increase in the water bill is too high compared to the improvements described to the environmental quality

8. I cant pay na increase in my watter bill
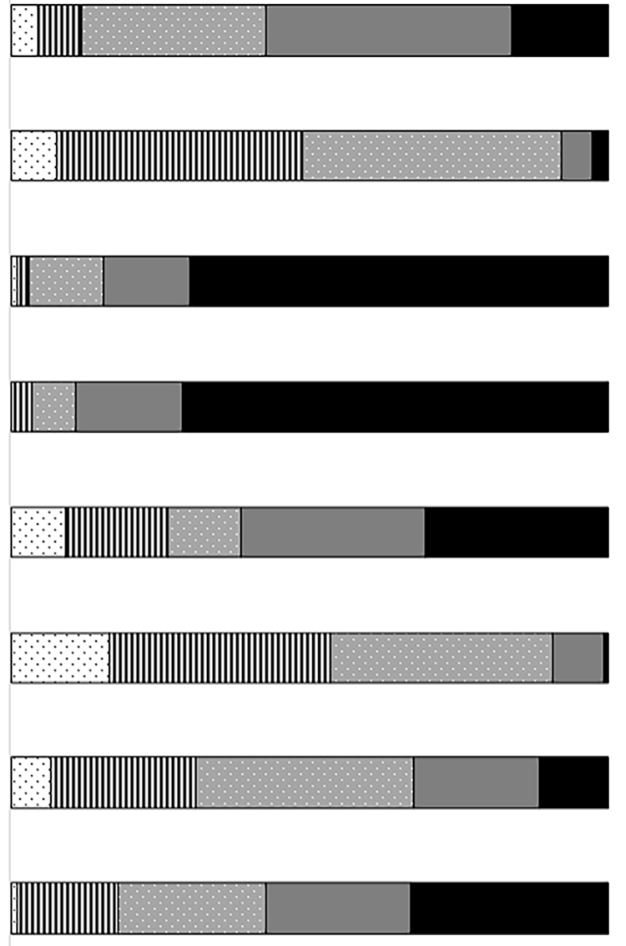

$\begin{array}{lllllllllll}0 & 10 & 20 & 30 & 40 & 50 & 60 & 70 & 80 & 90 & 100\end{array}$ $\%$ fully agree

Fig. 3. Motives that justify a negative answer in the willing to pay for nature's conservation in the Biophysical Interest Zone of Avencas. The bars represent the five levels of the Likert scale in percentage values. 
1. I use the Biophysical Interest Zone of Avencas and the volunteer work is a leasure activity in the area

2. I want to contribue to the aquatic environment protection and for the preservation of the aquatic animals and plants

3. Moraly I felt that this was the whright answer

4. I always give my time for natures conservation volunteer work

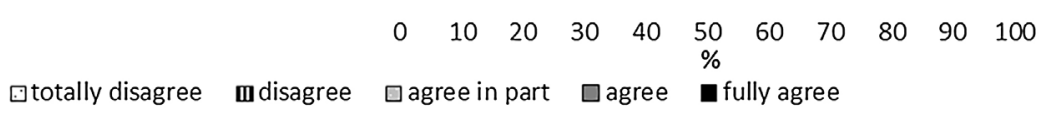

Fig. 4. Motives that justify a positive answer in the willingness to give time in form of volunteer work in nature's conservation in the Biophysical Interest Zone of Avencas. The bars represent the five levels of the Likert scale in percentage values.

1. I do not believe that the environmental quality will improve the way it was described

2. The users of the Biophysical Interest Zone of Avencas are the ones that should do volunteer work to improve the environmental quality

3. I think that the actual environmental quality is enough

4. I woul rather do volunteering in another place

5. I do not have time for volunteer work

$$
\square \text { totally disagree mdisagree }
$$
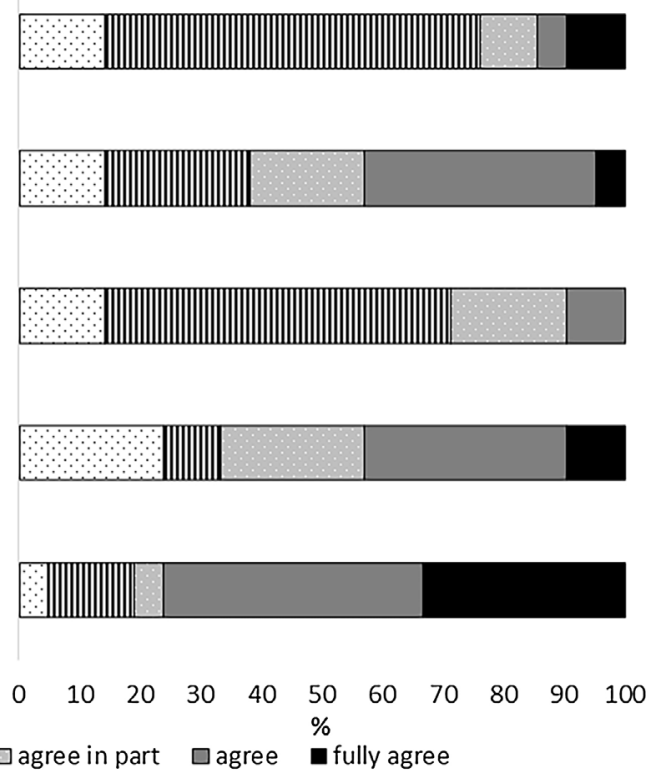

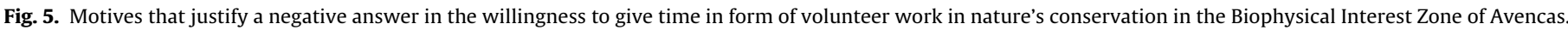
The bars represent the five levels of the Likert scale in percentage values.

class $^{1}$ while the national average income class ranged between 500 and $1000 €$ ) (Table 1 ).

Regarding the possible differences in age of individuals from the different groups analyzed, it was recorded an average age of 40.18 years-old in Group 1 and 44.38 years old in Group 2, therefore this different characteristics of the two groups didn't influence its age homogeneity.

\subsection{Value assigned for costal zones conservation in monetary values and voluntary work and relation with its usages}

In both groups examined, the analyses of Table 2 revealed that the predisposition of the respondents to pay for an extra tax in their

\footnotetext{
1 About one third of the respondents did not report their household income. The average household income class of 1001-2000€ assumed in this study is calculated for those respondents who stated their monthly household income.
}

water bill (to contribute to nature conservation at the Biophysical Interest Zone of Avencas) decreases with distance. The maximum percentage of the individuals willing to pay an extra were located in Cascais, but this number decreases in Almada and is null in Aveiro. The major difference in medium salary's is verified between Cascais and Almada (111 $€$ different) (Pordata, 2013). However, these were not the municipalities recording the greater differences in WTP values. The largest difference in WTP was recorded between Cascais and Aveiro, therefore the distance factor overcomes the availability of income per household.

In Group 1, 32.87\% of the respondents were willing to pay some monetary contribution to maintain and conserve the ZIBA system (Table 2). From those, $81 \%$ have chosen the minimum possibility ( $5 €$ per month, corresponding to $60 €$ per year) (Table 3 ).

In the same group, $63 \%$ of the respondents would also be available to conduct some volunteer work in nature's conservation. From these respondents, $44 \%$ of the people that chose to give time in the form of volunteer work chose the minimum time class avail- 
Table 1

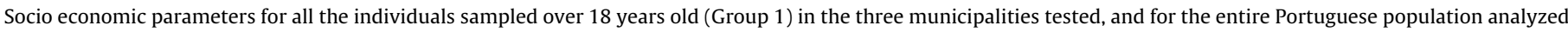
in the 2011 census (INE, 2011)

\begin{tabular}{|c|c|c|c|c|c|}
\hline $\mathrm{n}$ & $\begin{array}{l}\text { Total } \\
289\end{array}$ & $\begin{array}{l}\text { Cascais } \\
93\end{array}$ & $\begin{array}{l}\text { Almada } \\
97\end{array}$ & $\begin{array}{l}\text { Aveiro } \\
99\end{array}$ & Portugal \\
\hline Age (mean years) & 40.18 & 44.18 & 39.13 & 37.44 & 41.16 \\
\hline $\begin{array}{l}\text { Gender (\%) } \\
\text { Woman } \\
\text { Men }\end{array}$ & $\begin{array}{l}61.25 \\
38.75\end{array}$ & $\begin{array}{l}65.59 \\
34.41\end{array}$ & $\begin{array}{l}60.82 \\
39.18\end{array}$ & $\begin{array}{l}57.58 \\
42.42\end{array}$ & $\begin{array}{l}52.2 \\
47.8\end{array}$ \\
\hline $\begin{array}{l}\text { Education level (\%) } \\
\text { Elementary school } \\
\text { Middle school } \\
\text { High school } \\
\text { University or more } \\
\text { Household (average number) }\end{array}$ & $\begin{array}{l}6.92 \\
8.30 \\
35.99 \\
48.10 \\
2.86\end{array}$ & $\begin{array}{l}11.83 \\
7.53 \\
30.11 \\
48.39 \\
2.39\end{array}$ & $\begin{array}{l}7.22 \\
15.46 \\
30.93 \\
46.39 \\
3.00\end{array}$ & $\begin{array}{l}2.02 \\
2.02 \\
46.46 \\
49.49 \\
2.91\end{array}$ & $\begin{array}{l}24.60 \\
32.40 \\
18.50 \\
15.00 \\
2.60\end{array}$ \\
\hline $\begin{array}{l}\text { Household monthly income (\%) } \\
\text { 1-500€ } \\
500-1000 € \\
1001-2000 € \\
2001-3000 € \\
>3001 €\end{array}$ & $\begin{array}{l}5.88 \\
17.65 \\
22.15 \\
6.23 \\
2.77\end{array}$ & $\begin{array}{l}11.83 \\
17.20 \\
32.26 \\
13.98 \\
8.60\end{array}$ & $\begin{array}{l}6.19 \\
19.59 \\
25.77 \\
5.15 \\
0.00\end{array}$ & $\begin{array}{l}0.00 \\
16.16 \\
9.09 \\
0.00 \\
0.00\end{array}$ & $\begin{array}{l}14.66 \\
37.37 \\
14.45 \\
14.00 \\
0.003\end{array}$ \\
\hline
\end{tabular}

Table 2

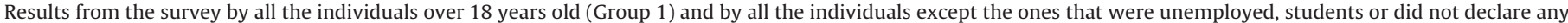
form of income (Group 2).

\begin{tabular}{|c|c|c|c|c|}
\hline & Total & Cascais & Almada & Aveiro \\
\hline \multicolumn{5}{|l|}{ Group $1(\%)$} \\
\hline Willing to pay $(€)$ & 32.87 & 67.74 & 32.99 & 0.00 \\
\hline Not willing to pay $(€)$ & 67.13 & 32.26 & 67.01 & 100 \\
\hline Willing to pay (hr) & 62.98 & 74.19 & 61.86 & 53.54 \\
\hline Not willing to pay (hr) & 7.27 & 11.83 & 10.31 & 0.00 \\
\hline \multicolumn{5}{|l|}{ Group 2 (\%) } \\
\hline Willing to pay $(€)$ & 50.75 & 69.86 & 42.50 & 0.00 \\
\hline Not willing to pay $(€)$ & 49.25 & 30.14 & 57.50 & 100 \\
\hline Willing to pay (hr) & 66.42 & 73.97 & 62.50 & 47.62 \\
\hline Not willing to pay (hr) & 11.94 & 10.96 & 20.00 & 0.00 \\
\hline
\end{tabular}

Table 3

Maximum annual value that people were willing to pay (WTP) for nature conservation at the Biophysical Interest Zone of Avencas.

\begin{tabular}{ll}
\hline $\mathrm{WTP}(€)$ & $\%$ \\
\hline 60 & 81.05 \\
120 & 10.53 \\
180 & 2.11 \\
240 & 0.00 \\
$>300$ & 3.16 \\
\hline
\end{tabular}

\section{Table 4}

Maximum annual number of hours allocated to volunteer work in nature's conservation at the Biophysical Interest Zone of Avencas in samples percentage. The willing to pay (WTP) estimation was calculated based on the average income of an individual in Portugal ( $5 € /$ hour).

\begin{tabular}{lll}
\hline $\begin{array}{l}\text { Maximum annual value for } \\
\text { volunteering (hr) }\end{array}$ & $\%$ & WTP $(€)$ \\
\hline 3 & 43.81 & 15 \\
18 & 36.19 & 90 \\
36 & 20.00 & 180 \\
\hline
\end{tabular}

able (Table 4). This people would give a morning or afternoon per year to nature's conservation. The correspondence with the average income of an individual in Portugal, would reveal a contribution of $15 €$ per year.

Interestingly, analyzing Table 2 we can perceive a decreasing trend as we move from the protected area in the respondent's willingness to contribute with time for nature conservation, this tendency is not as marked as it was with the monetary willingness to contribute. In Group 1, about 74\% of the individuals in Cascais were willing to give their time and effort to volunteer work. In Almada this percentage decreases to 62\% and Aveiro records 54\% of the individuals willing to give their time to volunteer work.

Comparing the results obtained for Group 1 and 2 (Table 2), it is possible to verify that in general, there are more people from Group 2 willing to pay for an extra tax in the water bill for nature's conservation, about $50 \%$. These results are according with expected, once there is a greater availability of the family budget for nature's conservation. These numbers are not as expressive when it comes to volunteer work.

In Group 1, 67.13\% of the respondents stated a zero willing to pay to conserve the ZIBA (Table 2). Given such high number of zero answers becomes essential to determine the true zero answers from the protest answers. Further scrutiny to the reasons for these answers is conducted in section 3.3.

There were ten different usages quantified in the inquiries for the coastal zones including several leisure activities, fishing, boating, dog walking, nature experiences, sports, etc. The majority of the population selected swimming at the beach (63\%) and outdoor walking (42\%) as the two main activities while visiting the coast, indicating that the leisure activities are the principal usage for the costal zones in the study area.

Regarding the correlation with the people willing to pay for the coastal zone conservation in Group 1 and their usage of the coastal zones, they were verified for: non-motor navigation $\left(r_{s}=0.158\right)$, swimming $\left(r_{s}=-0.269\right)$, sport fishing $\left(r_{s}=0.232\right)$ and nature experiences $\left(r_{s}=-0.016\right)$. On the contrary, in Group 2 (population with an income), only sport fishing recorded this correlation $\left(r_{s}=0.232\right)$. 


\subsection{Reasons underlying respondents' willing to pay for coastal} zones conservation

When inferring population regarding the underlying reasons that made them be willing to contribute for the system preservation is possible to perceive that it was related to bequest reasons. The respondents were concerned in conserving the good ecological quality of ZIBA for future generations (Fig. 2). This is corroborated by the high Spearman correlation registered to these variables $\left(r_{S}=-0.979\right)$ comparatively to the other five options.

The main reason that justifies a negative answer in the willing to pay for ZIBA's conservation is the respondents' belief that it should be the Municipality to support the environmental quality improvements (Fig. 3). This is corroborated by the Spearman correlation calculated to these variables $\left(r_{s}=0.881\right)$, once it was the highest record for this set of correlations.

The justifications for a positive answer in the willingness to give time in form of volunteer work for ZIBA's conservation can be analyzed in Fig. 4. The motive that assembles the greater consensus is that people want to contribute to the aquatic environment protection and for the preservation of the aquatic animals and plants. This was also corroborated by the Spearman correlation $\left(r_{s}=-0.571\right)$ for these two variables.

On the other hand, the main motive that would justify a negative answer would be the lack of time for volunteering work (Fig. 5). The highest Spearman correlation corroborated these graphical analy$\operatorname{ses}\left(r_{S}=0.975\right)$.

Aveiro Municipality respondents recorded 0\% of WTP, therefore it was necessary to determine if these were true zero answers or protest answers, from the justification options provided by this particular group. The main reasons presented for this answer by the respondents from Aveiro, point to true zero answers: the first reason stated was the "payer's polluter" reason (98\% of the respondents completely agree with this justification) and the second reason the distance factor, while $90 \%$ of the respondents completely agree with the Municipality supporting the costs of the environmental quality improvements.

\section{Discussion and conclusions}

There is a great societal valorization of coastal zones, and consequently of the services provided by these areas and several methods have been proposed to quantify this value. However, due to the inherent complexity of these systems, this remains a challenging task. Economists have long measured the value of goods that are routinely bought and sold in the markets, but ordinary markets do not exist for all nature goods or ecosystems services (Kahneman and Knetsch 1992; Carson 1998), so alternative methodologies have to be considered for these items.

With tight budgets, coastal managers face a challenge and every investment decision has to be well discussed and analyzed, nature or coastal zone conservation can be downgraded in the priority list of a public financial plan, where the wellbeing of the population must be maximized. The importance assigned by the population to the protected area is essential when evaluating the priority of investments at a national scale. The distance decay analysis of this study confirmed the expected greater affinity of the population closer to the area being valued, due to its usage and proximity (Pate and Loomis 1997; Atkins et al., 2007). People surveyed in the council of the protected area (Cascais) were the ones with the highest records of WTP however, $40 \mathrm{Km}$ away from ZIBA, respondents that are not regular users of the area, are still willing to pay an extra tax for natures conservation of this place, revealing its importance in the Lisbon Metropolitan Area. The small size of this particular protected area and its ecological importance in a local level, down- grades its importance at a national scale, therefore conservation funding for this type of protected area should be assigned in local management budgets like Municipalities or regional funding.

The valuation of this protected area could also be recognisable in the time people are willing to give for coastal zone conservation, $66.42 \%$ were willing to give one morning a year. The contact with nature in urban areas can be difficult, and public parks or public beaches provide ecosystem services greatly valued by the population, namely the leisure service provided by these places, were one can avoid the daily stress. The main reasons presented by the respondents indicate a strong engagement with coastal zone conservation and mostly the lack of time is an obstacle to give time for this activity. These results are accordant to García-Llorente et al. (2015) were the satisfaction of conserving species is the main reason in engaging public support for conservation, particularly in urban areas. This is also an interesting result for local managers; voluntary activities involving nature's conservation in the coastal zone are not very expensive and could give a great fulfillment to local populations, being an affordable way to achieve both social and ecological objectives. The maintenance of the beach cleanness and the improvement of social activities is referred in Turkey (Birdir et al., 2013) as the main reason for WTP for conservation of the coastal zone. While in Greece, the previous respondents' participation in environmental protection programs by paying an amount was the main cause presented by the respondents (Halkos and Matsiori 2012). However, these reasons are not always enough to engage in nature conservation, in Spain the population was not prepared to pay increased taxes to achieve a better quality of the urban coast of Cadiz (Alves et al., 2014).

In this study, the main motivation, for a positive willing to pay in the conservation of the Biophysical Interest Zone of Avencas is the good investment for generations to come, revealing the usage proximity of the respondents. In fact, sport fishers were the ones assigning a greater willing to pay for ZIBAs conservation probably because in Portugal this particular type of user already pays a fee to fish, and have every interest in maintaining the marine ecosystem for continuation of this practice. A percentage of $50.75 \%$ of the respondents were willing to pay an extra tax in the water bill for the conservation of ZIBA. The majority of these respondents were available to give $5 €$ a month per household ( $60 €$ annually) mainly because they consider that this is a good investment for generations to come, expressing the importance assigned to the existence of the area (non-use value). These results are consistent with the values determined by other studies for the coastal zones (e.g. RamajoHernandez and Saz-Salazar 2012), however to determine an exact amount is very challenging.

Most commonly, economic and ecological literatures do not appear coupled, and the great test remains in communicating ecological changes in stated preferences surveys, were the valuation vehicle is economic. The selection of indicators in the survey design has to be transparent in the ecological outcomes that respondents are being asked to value and ways in which these relate to the ecological information presented (Zhao et al., 2013). Bias induced by scope insensitivity, complex policy information, time constraints on a respondents valuation decision and strategic effects that arise as a respondent attempts to influence policy outcomes (Hoehn, 1987) especially in an economic crisis scenario, can also influence the obtained results. Nevertheless, a study conducted with actual payments on the willing to pay for preservation of species did not indicate that choice experiments suffer from overstatement in hypothetical willing to pay (Navrud 1992).

In contingent valuation studies, the willing to pay is a methodology greatly applied; however, the results can be greatly influenced by the low family budget. In many empirical contingent valuation studies, household size, i.e. the number of household members, appears negatively correlated with stated household willing to 
pay for the maintenance of environmental projects (Ahlheim and Schneider 2013). The willing to give up time as an alternative to traditionally willing to pay studies with a monetary contribution, can be a good alternative when facing such scenarios of populations with income limitations (García-Llorente et al., 2015) particularly because the availability to pay for coastal zone conservation is not proportional to the available budget per household.

In Portugal the public access to the beach or to a protected area, as a Natural Park cannot be constrain by payment, although according to the municipal experience it would be well accepted by the tourists an entrance fee to some protected areas. The hypothetical payment vehicle adopted, in form of a tax in the water bill, was a good alternative for this contingent valuation study of the coastal zone. The results of this study highlight the importance assigned by the population to the ecosystems services of a coastal protected area and its conservation. The investment made by the government will have a local and regional impact in the living conditions of the population, therefore these considerations should be taken in to account when conducting cost benefit analysis, for allocating public funds to investments in the coastal conservation. The willing to give time as a non-monetary technique revealed to be useful and coherent with the willing to pay results in this case study. The implications of these results for the governance of the coastal zones, revealed the public support in voluntary conservation actions as well as its valuation by the population.

The scientific community is currently communicating inefficiently to policymakers and the public what is the link between biodiversity changes and human wellbeing (Adamowicz 2004; Ressurreição et al., 2012), and a more complete dialogue between all stakeholders must be undertaken in order to better manage protected areas and promote coastal zone conservation.

In this context, the next challenge would be transposing this type of studies to policymakers and coastal stakeholders, the use of comprehensive numerical language would be necessary to include in annual budgets managed by the governments in a larger temporal scale to achieve a sustainable management.

\section{Acknowledgments}

This study was supported by Fundação para a Ciência e a Tecnologia (FCT) through the strategic project UID/MAR/04292/2013 granted to MARE. The authors are grateful for the help of Ângela Gandarinho, Mariana Velez, Patricia Valentim, Tiago Policarpo and Inês D. in the questionnaires implementation. The authors are also grateful for the valuable comments and revisions by $\mathrm{Dr}^{\underline{a}}-$ Rute Pinto.

\section{References}

Adamowicz, W.L., 2004. What's it worth? An examination of historical trends and future directions in environmental valuation. Aust. J. Agric. Resour. Econ. 48, 419-443, http://dx.doi.org/10.1111/j.1467-8489.2004.00258.x.

Ahlheim, M., Schneider, F., 2013. Considering household size in contingent valuation studies. Environ. Econ. 4, 112-123 http://businessperspectives.org/ journals_free/ee/2013/ee_2013_01_Ahlheim.pdf.

Alves, B., Benavente, J., Ó, Ferreira, 2014. Beach users' profile, perceptions and willingness to pay in Cadiz (SW Spain). J. Coast. Res. 70, 521-526, http://dx.doi. org/10.2112/SI70-088.1.

Atkins, J.P., Burdon, D., Allen, J.H., 2007. An application of contingent valuation and decision tree analysis to water quality improvements. Mar. Pollut. Bull. 55, 591-602, http://dx.doi.org/10.1016/j.marpolbul.2007.09.018.

Batela, A., Bastab, J., Mackelworth, P., 2014. Valuing visitor willingness to pay for marine conservation -the case of the proposed Cres-Lošinj Marine Protected Area. Croatia Ocean Coast. Manage. 95, 72-80, http://dx.doi.org/10.1016/j. ocecoaman.2014.03.025.
Bateman, I.J., Carson, R.T., Day, B., Hanemann, M., Hanley, N., Hett, T., Jones-Lee, M., Loomes, G., Maurato, S., Ozdemiroglu, E., Pearce, D.W., Sugden, R., Swanson, J., 2002. Economic Valuation with Stated Preference Techniques: A Manual. Edward Elgar Cheltenham, UK.

Birdir, S., Ünal, O., Birdir, K., Williams, A., 2013. Willingness to pay as an economic instrument for coastal tourism management: cases from Mersin, Turkey. Tour. Manag. 36, 279-283, http://dx.doi.org/10.1016/j.tourman.2012.10.020.

Boyle, K.J., Bishop, R.C., 1988. Welfare measurements using contingent valuation: a comparison of techniques. Am. J. Agric. Econ. 70 (1), 20-28.

Carson, R.T., 1998. Valuation of tropical rainforests: philosophical and practical issues in the use of contingent valuation. Ecol. Econ. 24, 15-29.

Ferreira, A., Seixas, S., Marques, J.C., 2015. Bottom-up management approach to coastal marine protected areas in Portugal Ocean. Coast. Manag. (B) 118, 275-281, http://dx.doi.org/10.1016/j.ocecoaman.2015.05.008.

García-Llorente, M., Castro, A.J., Quintas-Soriano, C., López, I., Castro, H., Montes, C. Martin-López, B., 2015. The value of time in biological conservation and supplied ecosystem services: a willingness to give up time exercise. J. Arid Environ. 124, 13-21, http://dx.doi.org/10.1016/j.jaridenv.2015.07.004.

Gelcich, S., Amar, F., Valdebenito, A., Castilla, J.C., Fernandez, M., Godoy, C., Biggs, D., 2013. Financing marine protected areas through visitor fees: insights from tourists willingness to pay in Chile. Ambio 42 (8), 975-984, http://dx.doi.org/ 10.1007/s13280-013-0453-z.

Gladstone, G., 2007. Requirements for marine protected areas to conserve the biodiversity of rocky reef fishes. Aquat. Conserv. Mar. Freshw. Ecosyst. 17, 71-87, http://dx.doi.org/10.1002/aqc.759.

Halkos, G., Matsiori, S., 2012. Determinants of willingness to pay for coastal zone quality improvement. J. Socio-Econ. 41, 391-399, http://dx.doi.org/10.1016/j. socec.2012.04.010.

Hoehn, J.P., 1987. Contingent valuation in fisheries management: the design of satisfactory contingent valuation formats. Trans. Am. Fish. Soc. 116 (3), 412-419, 10.1577/1548-8659(1987)116<412:CVIFM>2.0.CO;2.

INE, (2011). Instituto Nacional de Estatistica/Statistics National Institute. http://www.ine.pt/xportal/xmain?xpid=INE\&xpgid=ine_main. (Accessed 30 January 2015).

Kahneman, D., Knetsch, J.L., 1992. Valuing public goods: the purchase of moral satisfaction. J. Environ. Econ. Manag. 22, 57-70, http://dx.doi.org/10.1016/ 0095-0696(92)90019-s.

Kriström, B., 1990. Valuing environmental benefits using the contingent valuation method -an econometric Analysis. Umea Econ. Stud. 219, 196, UMEA http:// www.diva-portal.org/smash/get/diva2:728650/FULLTEXT02.pdf.

Likert, R., 1932. A technique for the measurement of attitudes. Arch. Psychol. 22, 53 http://www.voteview.com/pdf/Likert_1932.pdf.

Mitchell, R.C., Carson, R.T., 1989. Using Surveys to Value Public Goods: The Contingent Valuation Method. John Hopkins University Press, Washington, D.C.

Navrud, S., 1992. Willingness to pay for preservation of species - an experiment with actual payments. In: Pricing the European Environment. Oxford University Press, Inc, Oxford.

POOC, (1998). Plano de Ordenamento da Orla Costeira Cidadela - São Julião da Barra/Coastal Zone Management Plan Cidadela -São Julião da Barra http://www.apambiente.pt/index.php?ref=x130. (Accessed 30 January 2015).

Pate, J., Loomis, J., 1997. The effect of distance on willingness to pay values: a case study of wetlands and salmon in California. Ecol. Econ. 20 (3), 199-207, http:// dx.doi.org/10.1016/s0921-8009(96)00080-8.

Pordata, 2013. Base de Dados de Portugal Contemporâneo (Accessed 10 January 2017) http://www. pordata.pt/Municipios/.

Ramajo-Hernandez, J., Saz-Salazar, S., 2012. Estimating the non-market benefits of water quality improvement for a case study in Spain: a contingent valuation approach. Environ. Sci. Policy 22, 47-59, http://dx.doi.org/10.1016/j.envsci. 2012.05.006.

Ressurreição, A.,Zarzycki, T., Kaiser, M., Edwards-Jones, G., Ponce Dentinho, T. Santos, R.S., Gibbons, J., 2012. Towards an ecosystem approach for understanding public values concerning marine biodiversity loss. Mar. Ecol. Prog. Ser. 467, 15-28, http://dx.doi.org/10.3354/meps09967.

Thompson, R.C., Crowe, T.P., Hawkins, S.J., 2002. Rocky intertidal communities: past environmental changes, present status and predictions for the next 25 years. J. Environ. Conserv. 29 (2), 168-191, http://dx.doi.org/10.1017/ s0376892902000115.

Whitehead, J.C., 1990. Measuring willingness-to-pay for wetlands preservation with the contingent valuation method. Wetlands 10,187-201, http://dx.doi. org/10.1007/BF03160832.

Zhao, M., Johnston, R.J., Schultz, E.T., 2013. What to value and how? Ecological indicator choices in stated preference valuation. Environ. Resour. Econ. 56, 3-25, http://dx.doi.org/10.1007/s10640-013-9636-0. 